\title{
Closing of the American mind
}

\author{
ABR THOMSON, MD, PHD, FRCPC
}

Written by Allan Bloom (1987). A Touchstone Book, published by Simon and Schuster, Inc: New York, London, Toronto, Sydney, Tokyo.

\section{Education fails when the soul of the teacher is obscured.}

$\mathrm{H}$ IGHER EDUCATION HAS FAILED DEMOCRACY AND impoverished the souls of today's students. Important and controversial...could - and should - serve as a major resource in the effort to rethink the very nature and purpose of American higher education."

This includes the plying of our trade, medical education.

Throughout this book I have referred to Plato's 'Republic' which is for me the book on education, because it really explains to me what I experience as a man and a teacher. Academics, even those describing themselves as existentialists, very seldom offer themselves publicly and frankly as individuals, as persons. Saul Bellow, Foreword, Closing of the American Mind, 1987.

Bloom suggests that "what each generation is can best be discovered in its relation to the permanent concerns of mankind." This being the case, then "the soul, so the teacher must think, may at the outset of education require extrinsic rewards and punishment to motivate its activity; but in the end that activity is its own reward and is self-sufficient." Is this part of the educational process today? Is this the education we give our medical students? Bloom suggests that

book learning is most of what a teacher can give - properly administered in an atmosphere in which its relation to life is plausible. Life will happen to his students. The most he can hope is that what he might give will inform life.

Informed education, like informed consent, requires insight, honesty and frankness. Do we as medical teachers provide our students with part of ourselves, our ethics, our hopes and dreams? Our virtue as teachers might be in teach-

Correspondence and reprints: Dr ABR Thomson, University of Alberta, 519 Robert Newton Research Building, Edmonton, Alberta T6G 2C2 ing relativism to open the minds of our students to the unknown; more importantly, we must consider that not all of our students will be scholars. Can we not provide them with the moral values of openness, honesty and compassion?

We must become involved in the education of the democratic personality with an openness "to all kinds of men, all kinds of lifestyles, all kinds of ideologies...when there are no shared goals or visions of the public good, is the social contract any longer possible?" Installing in our students a smattering of facts without conveying to them the spirit, the joy, the passion of caring for one's fellow human beings - that is the hollowness of medical school, providing a major basis for disillusionment with facts and figures, and never enough humour or relevance. The self-centredness of today, the practice of protective medicine to avoid the ravages of another disturbed profession, can be understood but never justified by the very means some schools use to select students for admission. A recent interviewee was asked to describe himself in 30 words or less: "I have an 8.3 average." A future caregiver? What a low point for human existence!

Bloom suggests that this individualism has been reinforced by

another unintended and unexpected development, the decline of the family, which was the intermediary between the individual and society. This indeterminate or open-ended future and the lack of a binding past can mean that the souls of young people are in a condition like that of the first man in the state of nature - spiritually unclad, unconnected, isolated, with no inherited or unconditional connection with anything or anyone. They can be anything they want to be, but they have no particular reason to want to be anything in particular.

Balanced against this individualism and egalitarianism is the battle cry of 'debilitated normalcy', the common denominator of mediocrity. With the many opportunities available to young people today, they can, if they wish, extricate themselves gracefully from their pasts. To build a greater future with the wisdom to find peace and social justice for the young, the unborn, the aged, the female, the homosexual, and the mentally or emotionally handicapped - but not for the 8.3 misfit.

Will the thankfully major number of women in medicine 
today provide the profession with peace and understanding, or will it be the springboard for a feminism viewing "the position of women as a result of nurture and not nature"? Equal opportunity and equal risk. Let us hope that the tenderness and caring brought by women to death and dying may nurture an even greater compassion for patients, and thereby redirect the intensity and legal largesse of defensive medicine and cost-effectiveness.

Women are no longer willing to make unconditional and perpetual commitments on unequal terms and, no matter what they hope, nothing can effectively make most men share equally the responsibilities of childbearing and child rearing.

Our challenge, then, is to define the future and provide medical women today with the equal terms they need, for it is their sensitivity and love of life which will drive the male medical workaholic to seek fulfillment in more than signs and symptoms. And yet this opening of the individual has its risks - what will become of commitment to patients? Bloom suggests that "young people today are afraid of making commitments, and the point is that love is commitment, and much more." Will that greater love of self so prevalent today lead to a greater love of mate, family, patients or profession?

With machismo discredited, the positive task is to make men caring, sensitive, even nurturing, to fit the restructured family...It is indeed possible to soften men...men tend to undergo this re-education somewhat sullenly but studiously, in order to avoid the opprobrium of the sexist label and to keep peace with their wives and girlfriends! Persons deeply committed to values are admired. Their intense belief, their caring or concern, their believing in something, is the proof of autonomy, freedom and creativity.

Mankind has had concerns throughout history about the care of his body versus the care of his soul, expressed in the opposition between desire and virtue. "A good man used to be the one who cares for others, as opposed to the man who cares exclusively for himself." Now the good man is the one who knows how to care for himself, as opposed to the man who does not.

Culture is what makes possible, on a higher level, the rich social life which constitutes a people, their customs, styles, tastes, festivals, rituals, gods - all that binds individuals together to form a group with roots, a community in which they think and will, the people a moral unity, and the individual united within himself. This becomes the peak expression of man's creativity and dignity.

\section{Universities should be a transforming experience in which}

the successful university is the proof that a society can be devoted to the well-being of all, without stunting human potential or imprisoning the mind to the goals of the regimen." The university's task is "always to maintain the permanent questions front and centre. The most important function of the university in an age of reason is to protect reason from itself, by being the model of true openness. Hence, without having the answers, the university knows what openness is and knows the question. There the university risks less by having intransigently high standards than by trying to be too inclusive, because the society tends to blur standards in the name of equality. The university as an institution must compensate for what individuals lack in a democracy and must encourage its members to participate in its spirit. It must be contemptuous of public opinion because it has within it the source of autonomy - the quest for an even discovery of the truth according to nature. The university must resist the temptation to try to do everything for society. The university is only one interest among many and must always keep its eye on that interest for fear of compromising it in the desire to be more useful, more relevant, more popular. Aristophanes recaptures for us the absurdity of a grown man who spends his time thinking about gnats' anuses. We have been too persuaded of the utility of science to perceive how far the scientist's perspective is from that of a gentleman, how shocking and petty the scientist's interests appear to a man who is concerned with war and peace, justice, freedom and glory. If science is just for curiosity's sake, which is what theoretical men believe, it is nonsense, and immoral nonsense, from the viewpoint of practical men.

Do our students think while they do? Bloom sug. gests that

if the doer is not a thinker, then it is doubtful whether the thinker can understand the doer. No public career these days - not doctor, nor lawyer, nor politician, nor journalist, nor businessman, nor entertainer - has much to do with humane learning. An education, other than purely professional or technical, may even seem to be an impediment. That is why a countervailing atmosphere in the university would be necessary for the students to gain a taste for intellectual pleasures and learn that they are viable. The net effect of the student's encounter with the college catalogue is bewilderment and very often demoralization. It is just a matter of chance whether he finds one or two professors who can give him an insight into one of the great visions of education that have been the distinguishing part of every civilized nation. So, just as in the ' 60 s universities were devoted to removing requirements, in the ' 80 s they are busy with attempts to put them back in, a much more difficult task.

\section{To repeat,}

the crisis of liberal education is a reflection of a crisis at the peak of learning, an incoherence and incompatibility among the first principles with which we interpret the world, an intellectual crisis of the greatest magnitude, which constitutes the crisis of our civilization. But perhaps it should be true to say that the crisis consists not so much in this incoherence but in our incapacity to discuss or even recognize it. For the scientist the humanities are recreation... and for the humanist the natural scientists are at best indifferent, at worst alien and hostile. It is a general rule that the students who have any chance of getting a liberal education are those who do not have a fixed career goal, or at least those for whom the university is not merely the training ground for a profession. Pre-med, pre-law and pre-business students are distinctively tourists in the liberal arts. Getting into those elite professional schools is an obsessive concern that tethers their minds. One cannot and should not hope for a general reform. The hope is that the embers do not die out.

And when was the last time your medical students were asked what they felt, what they were as persons, what they cared about? When was the last time you asked yourself?...That the embers do not die out. 


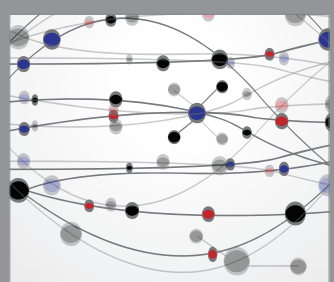

The Scientific World Journal
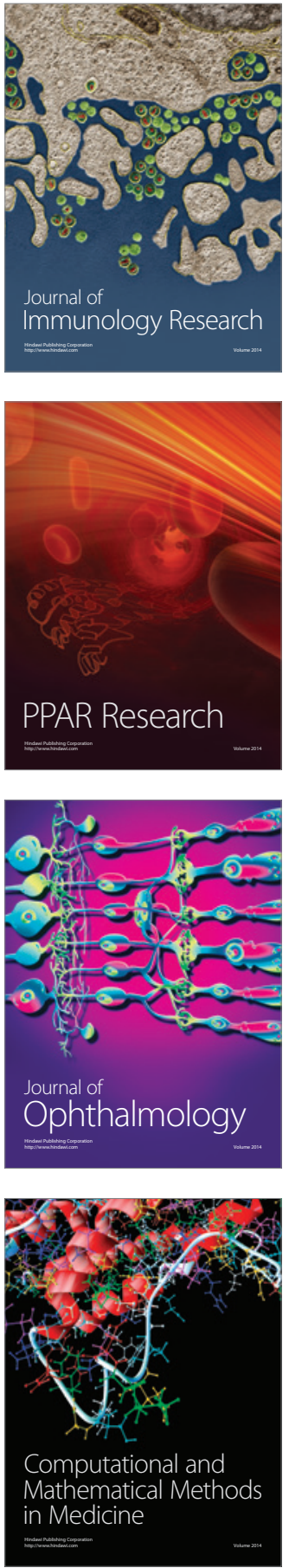

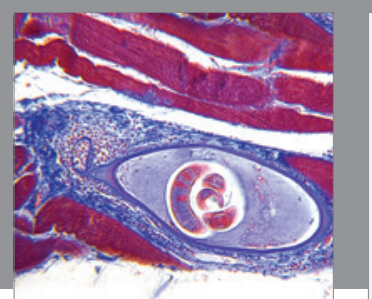

Gastroenterology Research and Practice

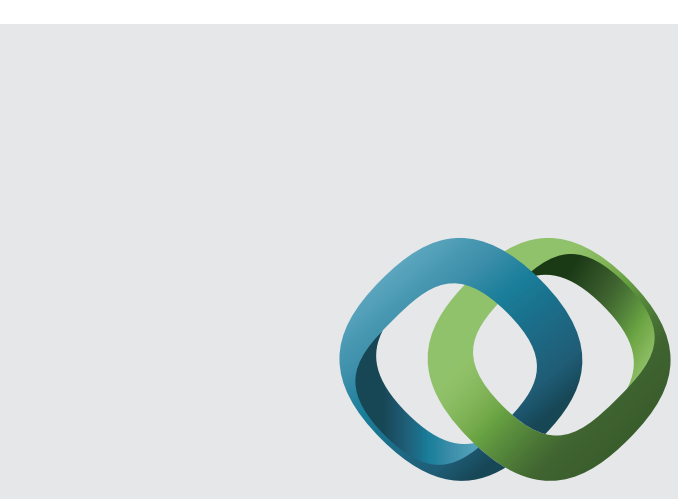

\section{Hindawi}

Submit your manuscripts at

http://www.hindawi.com
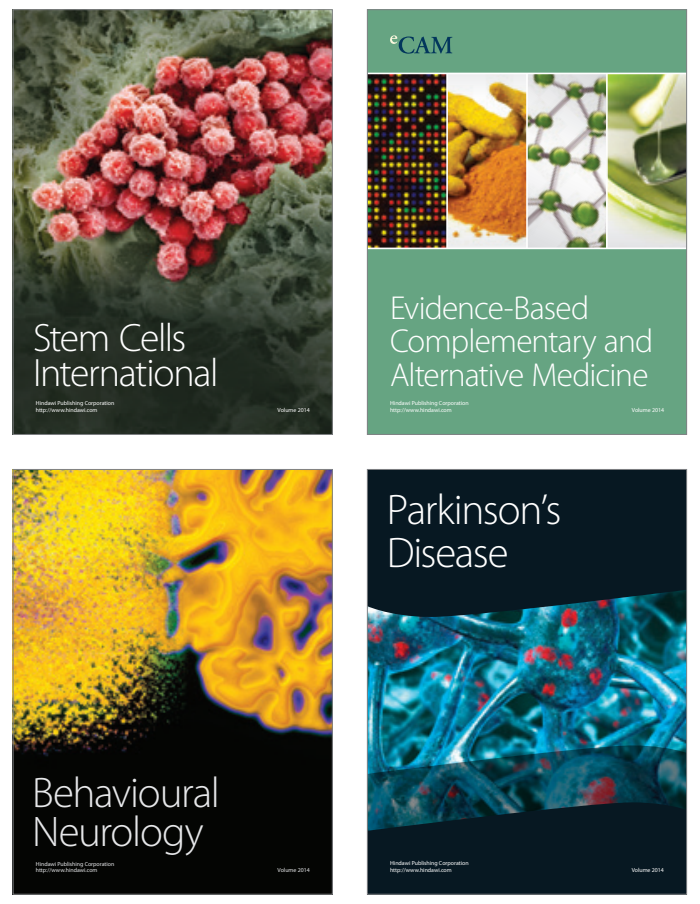
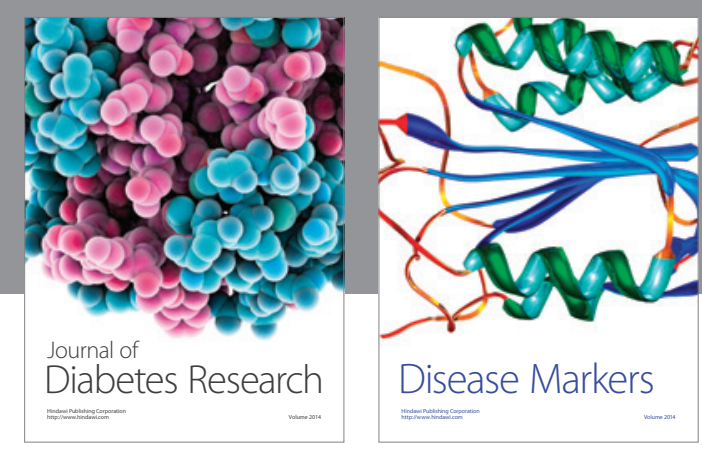

Disease Markers
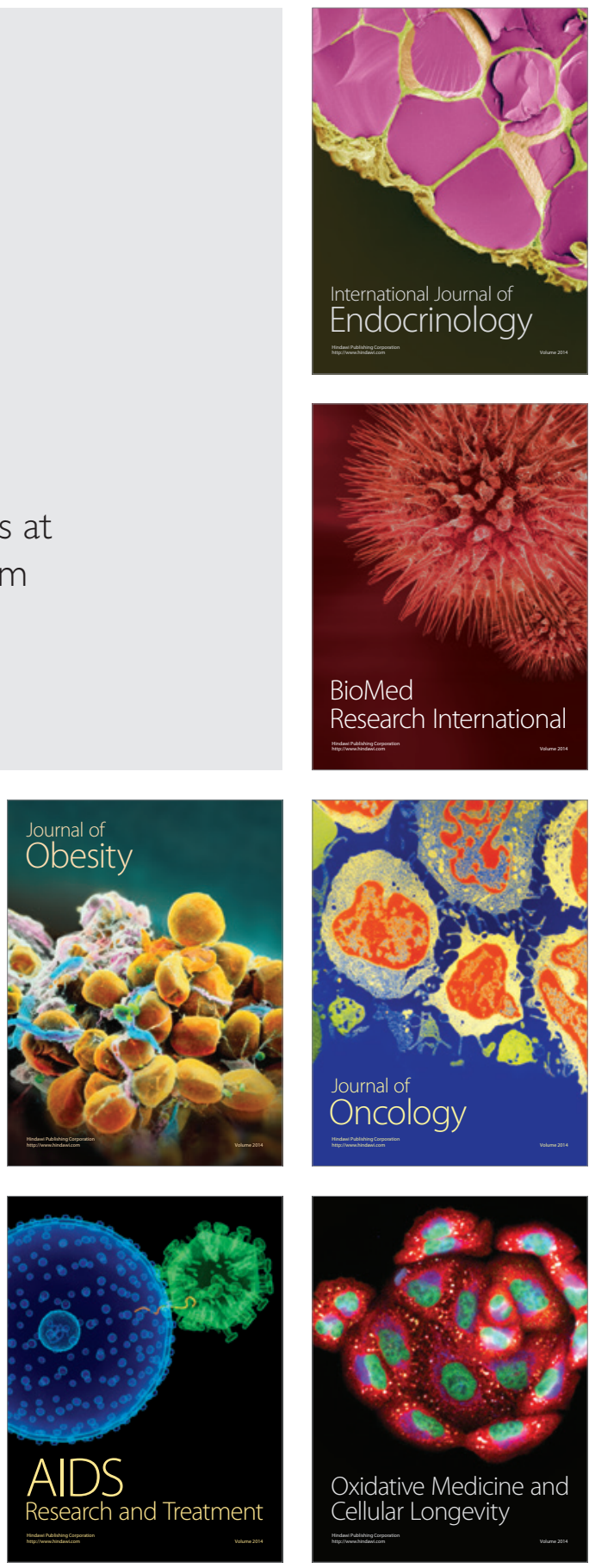